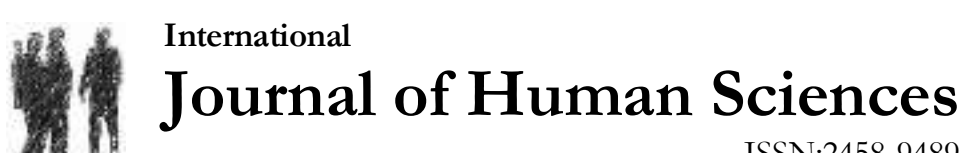 \\ ISSN:2458-9489
}

Volume 14 Issue 3 Year: 2017

\section{Evaluating the vocational thoughts of university students about the departments they are studying ${ }^{1}$}

\author{
Özlem Karakuş ${ }^{2}$
}

\begin{abstract}
The aim of this study is to reveal the vocational thoughts of university students about departments they are studying. The sample of the study consists of 1040 students; $608(60,6 \%)$ of them are female, and $396(39,4 \%)$ of them are male students who are studying in the different faculties of the Selçuk University (Health Sciences, Law, Veterinary, Collage of Science, Faculty of Letters, Communication, Agriculture, Faculty of Economics and Administrative Sciences, Engineering), and they selectedby random sampling method. The average of age of the students is varying between 19 and 39. The average of age is 22. During the data collection phrase "Demographic Information Form"; during the evaluation of the data frequency polygon is used.
\end{abstract}

At the end of the study it is detected that 743 (74\%) of the students are willingly, and $261(26 \%)$ of the students are unwillingly came to the department they are studying. Also; the uneasiest situation for the students' future is to not find a job for $492(49,0 \%)$ of them, financial difficulties for 282 $(28,1 \%)$ of them, mate selection for $230(22,9 \%)$ of them. At the same time, it is confirmed that $679(67,6 \%)$ of the students want to work in public sector, and $325(32,4 \%)$ of them want to work in private sector after graduation. It is seen that $198(19,7 \%)$ of the students define unemployment as not to find a job in public sector, and $806(80,3 \%)$ of them define unemployment as not to earn income. $458(45,6 \%)$ of the students who participated to study are pleased with the employment opportunities, but $546(54,4 \%)$ of them are not. It is detected that students of the departments of Social Work, English Language and Literature, Civil and Mechanical Engineering are pleased with employment opportunities after graduation, but the students of the departments of Statistic, Biology, Chemistry, History of Art, Sociology are not. Also, 395 (39,3\%) of the students stated that they think they will be unemployed when they graduated, $609(60,7 \%)$ of them do not think they are going to be an unemployed; departments of Social Work, English Language and Literature, Civil and Mechanical Engineering students stated that they are not going to become unemployed when they graduated,but the students of the departments of Statistic, Biology, Chemistry, History of Art, Sociology stated that they are going to become unemployed.

Most of the university students choose their departments willingly. What makes university students anxious most is being unemployed. Students want to work in public sector when they graduate. For the unemployment anxiety that students are experiencing, state has to develop new policies related with employment. In order to make students believe that they would find job easily, apart from the departments they enroll in, alternative ways for career development can be provided.

Keywords: University students; unemployment; occupation.

${ }^{1}$ This article was presented orally at VIII. European Conference on Social and Behavioral Sciences September 3-6, 2015, Belgrade, Serbia.

${ }^{2}$ Associate Prof. Dr. University of Selçuk, Faculty of Health Science, Department of Social Work, ozikarakus@gmail.com 
Karakuş, Ö. (2017). Evaluating the vocational thoughts of university students about the departments they are studying. Journal of Human Sciences, 14(3), 2643-2652. doi:10.14687/ihs.v14i3.4696

\section{Introduction}

Vocation is an important factor for an individual to develop and realize him/herself. Happiness of an individual is, in a way, related with choosing the suitable and satisfactory vocation (Doğramac1, 2008). In the literature, there are different vocation definitions. According to Kuzgun (1982) vocation is a complement of regular and orderly activities, those rules are decided by the society and acquired through education, done in order to earn one's life. According to another definition, vocation is the title that one performs in order to lead his/her life and this title is acquired generally as a result of an intense education, working, knowledge accumulation and increasing job-related skills (Vocation Guidance, 2008). Or, vocation is a law-regulated profession that is gained through a education and based on systematic knowledge and skills and this profession is done to earn money through producing useful goods for humans and providing them with services (Kuzgun, 2003; Vocational Guidance Instruction, 2010).

To have a Professional vocation requires obtaining job-related education (San, 1988). Vocational training provided in formal and informal education institutions enable an individual to have vocational competence documents like certificate and diploma. Individuals decide their vocations based on psychological (interest, value, skill) and social (socio-economic level- family relations) factors (Kuzgun, 2004). Even the social system related features (regime of the country, economic structures, and laws etc.) have an influence on vocation preferences (Korkut-Owen, 2008). It is known that not only one single criterion but several factors are relevant in choosing a vocation such as material benefits (Kars et al, 2004), career opportunity and job security etc. An individual when $\mathrm{s} / \mathrm{he}$ is in training as a candidate for a vocation not only learns about the area of application of the production or service, but also learns about job related role patterns (Soyer, 1996). Also, preferred vocation, determines the social status, level of income and private life of an individual (Korkut-Owen, 1998).

Most people have started to think about their future and make some plans before their school days. This initially completely emotional and imaginary attitude becomes more realistic with increasing age. Although vocation preference is an important matter for both individuals and society, one thing is certain that vocation preferences in Turkey mostly are coincidences (Yllmaz et al., 1996). It cannot be said for most of the individuals that they have enough knowledge about vocations, their job definitions and their opportunities (Anılan et al., 2008). In addition to that, it is no clear why and based on which criteria those people choose suitable vocations for themselves.

Every high school student in Turkey wants to enroll in a university. Based on the scores that they take from University Entrance Exam, they are placed into universities. While some students can enroll in their desired departments, lots of students enroll in not the ones they want but the ones whose scores are sufficient. While there has been an increasing demand for departments with better employment facilities (Kiyak, 2006), demand for the departments that could not provide easiness for employment has been decreasing. Regardless of employment prospects, lots of student in different departments continue their education. In Turkey, enrolling in a university might mean to acquire a profession and then find employment. Not being able to find a job can be evaluated as a significant problem. Even if they are happy with their departments, they have concerns about finding a job (Ylmaz, 2014). Not being able to know what will happen in the future is one of the major sources of anxiety (Cüceloğlu, 1996). Graduation, unemployment, job selection, and different responsibilities are some of the factors that increase senior university students' anxiety (Doğan \& Baş, 2003).

The reasons of the unemployment that is one of the most important problems societies experience have changed in time. Previously, uneducated population was affected by unemployment, but nowadays educated population as well is affected. Previously obtaining education equaled to be employed but in today's world it is not the case anymore. In Turkey, 
Karakuş, Ö. (2017). Evaluating the vocational thoughts of university students about the departments they are studying. Journal of Human Sciences, 14(3), 2643-2652. doi:10.14687/ihs.v14i3.4696

unemployment is not a novel problem. Rapid population increase, having a young population, unrecorded labor and not having enough area of employment are the reasons of unemployment (Harmanc1, 2014). Considering our country's population, which is predominantly young and workable, unemployment directly affects young population and young unemployment confronts us. It can be seen natural for young people not being able to find a job when they look for jobs for the first time. However, long-term unemployment had negative impacts on youngs. Basically, unemployment is the result of having more labor supply than demand or having less labor demand than labor supply (Ekin 2003; Korkmaz \& Mahiroğullar1, 2007). It is revealed in 2014 that (5 million 949 thousand) universite graduates are unemployed. In 2014, unemployment rate among university graduates is $12.9 \%$. It is known that one among ten unemployed is university graduate (GNAT, 2015). Universities prepare students to business life by up skilling their fundamental abilities. Increase in the number of universities bring with it increase in university graduates. This means that there will be more competition to get a job. This competition and unemployment problem leads to experiencing intenser unemployment anxiety (Aytaç \& Dursun, 2009). Faculty of Education and Faculty of Science and Letters graduate too many students and lots of teachers are waiting for appointment. Unemployment, beyond being an economic problem, is a multifaceted phenomenon with societal and individual aspects (Yüksel, 2003). In societies that experience unemployment densely, pessimism and future anxiety show up (Aytaç \& Keser, 2002). Senior students want to get a job from which they earn revenue. Students who perceive the process not being positive experience unemployment anxiety and in relation to that unhappiness (Aytaç \& Bayram, 2001). Developing the quality of workforce by graduating from a university is not enough for a good job and this increases young people's future uncertainty. Given their desire for secure and better paid jobs, university graduated young's unemployment lasts longer than unqualified labor's unemployment. When it comes to university students who maintain their education, it is inevitable for them not to experience anxiety of being unemployed (Dursun \& Ayaç, 2009; Kıcır, 2010).

Assessment of their departments by university students in terms of finding job will reveal, to a certain extent, the situations of those departments in terms of employment. Also, it presents that higher education policies concerning those departments have to be revisited. It is because, being a university-graduated unemployment has started to be a big source of hopelessness among young.

\subsection{The aims}

Based on the explanation above, the aim of the study is to evaluate departments that university students enrolled in based on certain criteria: whether they enrolled in the departments willingly, what makes them anxious about their future, whether they would find job easily or not, whether they appreciate the facilities provided by the departments or not.

\section{Method}

\subsection{Working group}

Study is carried out in line with general model of research. Population of the study consists of $3^{\text {rd }}$ and $4^{\text {th }}$ grade students of various departments (Health Sciences, Faculty of Architecture, Faculty of Veterinary, Faculty of Science and Letter, Faculty of Law and Faculty of Economics and Administrative Sciences) of Selcuk University in 2014- 2015 academic year. Working group that is chosen with random sampling consists of $608(60,6 \%)$ female and $396(39,4)$ male students. Students' age range varies between 19 and 39 and average is 22 (sd. 1,74).

\subsection{Data Collection method}

As a data collection method, the researcher designed questionnaire form. When questions are prepared, theoretical framework is taken into account. Based on this, questionnaire form is 
prepared. Questions of the form are examined by three experts and certain annexation and extraction is before finalizing the form. Although the questions are straightforward and multiple choice, in order to offer an alternative to respondents, by including "other" option, a broad range of responses are ensured.

\subsection{Analyzing data}

All the scores of the students who participated are included in research data. Research data is evaluated with SPSS 20.0 program. Descriptive statistical methods (frequency-percentage, chi square) were used in the data obtained about the children.

\section{Results}

Table 1. Students'Perceptions on the departments they enroll in

\begin{tabular}{|c|c|c|}
\hline Did you enroll in the department willingly? & $\begin{array}{l}\text { Number } \\
\text { (n) }\end{array}$ & $\begin{array}{l}\text { Percentage } \\
\quad(\%)\end{array}$ \\
\hline Yes & 743 & 74 \\
\hline No & 261 & 26 \\
\hline What makes you anxious about the future most? & $\begin{array}{l}\text { Number } \\
\text { (n) }\end{array}$ & $\begin{array}{l}\text { Percentage } \\
\quad(\%)\end{array}$ \\
\hline Could not find job & 492 & 49 \\
\hline Economic difficulties & 282 & 28 \\
\hline Mate choice & 230 & 23 \\
\hline In which sector you would like to work when you graduate? & $\underset{(\mathrm{n})}{\text { Number }}$ & $\begin{array}{l}\text { Percentage } \\
\quad(\%)\end{array}$ \\
\hline Public & 679 & 68 \\
\hline Private & 325 & 32 \\
\hline What is unemployment according to you? & $\underset{(\mathrm{n})}{\text { Number }}$ & $\begin{array}{l}\text { Percentage } \\
\quad(\%)\end{array}$ \\
\hline Could not find a job in public sector & 198 & 20 \\
\hline Could not earn income & 806 & 80 \\
\hline $\begin{array}{l}\text { Are you satisfied with the employment opportunities of the } \\
\text { department you enroll in? }\end{array}$ & Say1 (n) & Yüzde $(\%)$ \\
\hline Yes & 458 & 46 \\
\hline No & 546 & 54 \\
\hline Do you think you can find job easily when you graduate? & $\begin{array}{l}\text { Number } \\
\text { (n) }\end{array}$ & $\begin{array}{l}\text { Percentage } \\
\quad(\%)\end{array}$ \\
\hline Yes & 554 & 55 \\
\hline No & 450 & 45 \\
\hline Do you think you will be unemployed when you graduate? & $\begin{array}{l}\text { Number } \\
(\mathrm{n})\end{array}$ & $\begin{array}{l}\text { Percentage } \\
\quad(\%)\end{array}$ \\
\hline Yes & 395 & 39 \\
\hline No & 609 & 61 \\
\hline Total & 1004 & 100,0 \\
\hline
\end{tabular}

As it is seen in the chart, the question "did you enroll in the department willingly" is answered as yes by $743(74 \%)$ and $261(26 \%)$ as no. The most anxious situation for $492(49 \%)$ of participants is could not find job, for $282(28 \%)$ is economic difficulties and for $230(23 \%)$ is mate choice. In addition, it is seen that $679(68 \%)$ of students want to work in public sector; and 325 $(32 \%)$ of them want to work in private sector. Again, $198(20 \%)$ of students define unemployment as could not find a job in public sector and $806(80 \%)$ of them define as could not earn income. 
$458(46 \%)$ of participants are satisfied with job opportunities of their departments whereas 546 $(54 \%)$ of them are not satisfied with job opportunities. When the chart is examined, it is seen that $554(55 \%)$ of participants think they would find job easily; and $450(45 \%)$ of them do not think they would find job easily. $395(39 \%)$ of students think they would be unemployed and $609(61 \%)$ of them do not think that they would be employed.

Table 2. Crosstab on whether finding job is easy based on the departments

\begin{tabular}{|c|c|c|c|c|c|}
\hline \multirow{2}{*}{ Departments } & \multicolumn{5}{|c|}{ Do you think you can find job easily when you graduate? } \\
\hline & \multicolumn{2}{|c|}{ Yes } & \multicolumn{2}{|c|}{ No } & \multirow[b]{2}{*}{ Total } \\
\hline & $\begin{array}{l}\text { Number } \\
\text { (n) }\end{array}$ & $\begin{array}{c}\text { Percentage } \\
(\%)\end{array}$ & $\begin{array}{l}\text { Number } \\
\text { (n) }\end{array}$ & $\begin{array}{c}\text { Percentage } \\
(\%)\end{array}$ & \\
\hline Mathematic & 23 & 51 & 22 & 49 & 45 \\
\hline Statistics & 10 & 25 & 30 & 75 & 40 \\
\hline Biyology & 3 & 7 & 43 & 93 & 46 \\
\hline Chemistry & 24 & 56 & 19 & 44 & 43 \\
\hline Turkish Lit. & 15 & 37 & 26 & 63 & 41 \\
\hline English Lit. & 40 & 87 & 6 & 13 & 46 \\
\hline Sosyology & 6 & 21 & 22 & 79 & 28 \\
\hline Art History & 5 & 13 & 32 & 87 & 37 \\
\hline Public Administation & 23 & 56 & 18 & 44 & 41 \\
\hline Economics & 13 & 33 & 27 & 67 & 40 \\
\hline Business Administration & 18 & 42 & 25 & 58 & 43 \\
\hline Law & 34 & 81 & 8 & 19 & 42 \\
\hline Civil Engineering & 36 & 86 & 6 & 14 & 42 \\
\hline Chemistry Engineering & 21 & 51 & 20 & 49 & 41 \\
\hline Mechanical Engineering & 31 & 78 & 9 & 22 & 40 \\
\hline Industrial Engineering & 26 & 68 & 12 & 32 & 38 \\
\hline \multicolumn{6}{|l|}{ Electrical and Electronic } \\
\hline Engineering & 25 & 63 & 15 & 37 & 40 \\
\hline Radio,Television and Cinema & 18 & 46 & 21 & 54 & 39 \\
\hline Public Relations & 11 & 28 & 29 & 72 & 40 \\
\hline Agricultural engineering & 18 & 45 & 22 & 55 & 40 \\
\hline Veterinary & 37 & 88 & 5 & 12 & 42 \\
\hline Social Work & 38 & 95 & 2 & 5 & 40 \\
\hline Healthcare Management & 15 & 37 & 25 & 63 & 40 \\
\hline Midwifery & 64 & 91 & 6 & 9 & 70 \\
\hline Total & 554 & 55 & 450 & 45 & 1004 \\
\hline
\end{tabular}

When the chart is examined, responses in various departments are as follows: in Mathematic $23(51,1 \%)$ of students say yes, $22(49 \%)$ say no; in Statistics $10(25 \%)$ say yes, 30 (75\%) say no; in Biology, $3(7 \%)$ say yes, 43 (93\%) say no; in Chemistry $24(56 \%)$ say yes, $19(44 \%)$ say no; in Turkish Literature $15(37 \%)$ say yes, $26(63 \%)$ say no; in English Literature $40(87 \%)$ say yes, $6(13 \%)$ say no; in Sociology $6(21 \%)$ say yes, $22(79 \%)$ say no; in Art History $5(13 \%)$ say yes, $32(87 \%)$ say no; in Public Administration $23(56 \%)$ say yes, $18(44 \%)$ say no; in Economics 13 (33\%) say yes, 27 (67\%) say no; in Business Administration 18 (42\%) say yes, 25 (58\%) say no; in Law $34(81 \%)$ say yes, $8(19 \%)$ say no; in Civil Engineering $36(86 \%)$ say yes, $6(14 \%)$ say no; in Chemistry Engineering 21 (51\%) say yes, 20 (49\%) say no; in Mechanical Engineering 31 (78\%) say yes, $9(22 \%)$ say no; in Industrial Engineering $26(68 \%)$ say yes, $12(37 \%)$ say no; in Electrical and Electronic Engineering $25(63 \%)$ say yes, $15(37 \%)$ say no; in Radio Television and Cinema 18 
$(46 \%)$ say yes, 21 (54\%) say no; in Public Relations $11(28 \%)$ say yes, 29 (72\%) say no; in Agricultural Engineering $18(45 \%)$ say yes, $22(55 \%)$ say no; in Veterinary $37(87 \%)$ say yes, $5(12 \%)$ say no; in Social Work 38 (95\%) say yes, $2(5 \%)$ say no; in Healthcare Management $15(33 \%)$ say yes, $25(63 \%)$ say no; and in Midwifery $64(91 \%)$ say yes, $6(9 \%)$ say no.

Table 3. Crosstab of Whether Students Appreciate the Job Opportunities of Their Departments

\begin{tabular}{|c|c|c|c|c|c|}
\hline \multirow{3}{*}{ Departments } & \multicolumn{5}{|c|}{ Do you think you can find job easily when you graduate? } \\
\hline & \multicolumn{2}{|c|}{ Yes } & \multicolumn{2}{|c|}{ No } & \multirow[b]{2}{*}{ Total } \\
\hline & $\begin{array}{l}\text { Number } \\
\text { (n) }\end{array}$ & $\begin{array}{c}\text { Percentage } \\
(\%)\end{array}$ & $\begin{array}{l}\text { Number } \\
\text { (n) }\end{array}$ & $\begin{array}{c}\text { Percentage } \\
(\%)\end{array}$ & \\
\hline Mathematic & 24 & 53 & 21 & 47 & 45 \\
\hline Statistics & 8 & 20 & 32 & 80 & 40 \\
\hline Biyology & 3 & 7 & 43 & 93 & 46 \\
\hline Chemistry & 16 & 37 & 27 & 62 & 43 \\
\hline Turkish Lit. & 4 & 10 & 37 & 90 & 41 \\
\hline English Lit. & 37 & 80 & 9 & 20 & 46 \\
\hline Sosyology & 4 & 14 & 24 & 86 & 28 \\
\hline Art History & 1 & 3 & 36 & 97 & 37 \\
\hline $\begin{array}{c}\text { Public } \\
\text { Administation }\end{array}$ & 14 & 34 & 27 & 66 & 41 \\
\hline Economics & 13 & 33 & 27 & 67 & 40 \\
\hline $\begin{array}{c}\text { Business } \\
\text { Administration }\end{array}$ & 21 & 49 & 22 & 51 & 43 \\
\hline Law & 27 & 64 & 15 & 36 & 42 \\
\hline Civil Engineering & 34 & 81 & 8 & 19 & 42 \\
\hline $\begin{array}{c}\text { Chemistry } \\
\text { Engineering }\end{array}$ & 19 & 46 & 22 & 54 & 41 \\
\hline $\begin{array}{l}\text { Mechanical } \\
\text { Engineering }\end{array}$ & 31 & 78 & 9 & 22 & 40 \\
\hline $\begin{array}{l}\text { Industrial } \\
\text { Engineering }\end{array}$ & 24 & 63 & 14 & 37 & 38 \\
\hline $\begin{array}{l}\text { Electrical and } \\
\text { Electronic } \\
\text { Engineering }\end{array}$ & 21 & 53 & 19 & 47 & 40 \\
\hline $\begin{array}{l}\text { Radio,Television } \\
\text { and Cinema }\end{array}$ & 15 & 39 & 24 & 61 & 39 \\
\hline Public Relations & 9 & 23 & 31 & 77 & 40 \\
\hline $\begin{array}{l}\text { Agricultural } \\
\text { engineering }\end{array}$ & 12 & 30 & 28 & 70 & 40 \\
\hline Veterinary & 36 & 86 & 6 & 14 & 42 \\
\hline Social Work & 35 & 88 & 5 & 12 & 40 \\
\hline $\begin{array}{l}\text { Healthcare } \\
\text { Management }\end{array}$ & 4 & 10 & 36 & 90 & 40 \\
\hline Midwifery & 46 & 66 & 24 & 34 & 70 \\
\hline Total & 458 & 46 & 546 & 54 & 1004 \\
\hline
\end{tabular}

When the chart is examined, responses of the departments as follow: in Mathematic 24 $(53 \%)$ of students say yes, $21(47 \%)$ say no; in Statistics $8(20 \%)$ say yes, $32(80 \%)$ say no; in Biology, $3(7 \%)$ say yes, $43(93 \%)$ say no; in Chemistry $16(37 \%)$ say yes, $27(63 \%)$ say no; in 
Karakuş, Ö. (2017). Evaluating the vocational thoughts of university students about the departments they are studying. Journal of Human Sciences, 14(3), 2643-2652. doi:10.14687/ihs.v14i3.4696

Turkish Literature $4(10 \%)$ say yes, $37(90 \%)$ say no; in English Literature $37(80 \%)$ say yes, $9(20 \%)$ say no; in Sociology $4(14 \%)$ say yes, $24(86 \%)$ say no; in Art History $1(3 \%)$ say yes, $36(97 \%)$ say no; in Public Administration 14 (34\%) say yes, 27 (66\%) say no; in Economics 13 (33\%) say yes, 27 (67\%) say no; in Business Administration 21 (49\%) say yes, $22(52 \%)$ say no; in Law $27(64 \%)$ say yes, $15(36 \%)$ say no; in Civil Engineering $34(81 \%)$ say yes, $8(19 \%)$ say no; in Chemistry Engineering $19(46 \%)$ say yes, $22(54 \%)$ say no; in Mechanical Engineering 31 (78\%) say yes, 9 $(22 \%)$ say no; in Industrial Engineering $24(63 \%)$ say yes, $14(37 \%)$ say no; in Electrical and Electronic Engineering 21 (53\%) say yes, $19(47 \%)$ say no; in Radio Television and Cinema 15 (39\%) say yes, $24(61 \%)$ say no; in Public Relations $9(23 \%)$ say yes, 31 (77\%) say no; in Agricultural Engineering $12(30 \%)$ say yes, $28(70 \%)$ say no; in Veterinary $36(86 \%)$ say yes, $6(14 \%)$ say no; in Social Work $35(88 \%)$ say yes, $5(12 \%)$ say no; in Healthcare Management $4(10 \%)$ say yes, 36 (90\%) say no; and in Midwifery 46 (66\%) say yes, 24 (34\%) say no.

\section{Discussion}

"Did you enroll in the department willingly?" is answered as yes by 743 (74\%) of participants and as no by $261(26 \%)$. The situation that makes participants anxious most is could not find a job for $492(49 \%)$ of them; economic difficulties for $282(28 \%)$ of them and mate choice for $230(23 \%)$ of them. Also, it is seen that $679(68 \%)$ of students are willing to work in public sector and $325(32 \%)$ of students are willing to work in private sector. Again $198(20 \%)$ of students define could not find job in public sector as unemployment and $806(80 \%)$ of students define not earning income as unemployment. It is seen that $458(46 \%)$ of participants appreciate job opportunities of their departments whereas $546(54 \%)$ of the participants are not happy with the job opportunities of their departments. As it is seen, $554(55 \%)$ of participants think that they would find job easily when they graduate; $450(45 \%)$ of them do not think that they can find job easily. $395(39 \%)$ of students think they will be unemployed when they graduate, $609(61 \%)$ of them do not think that they will be unemployed when they graduate. Also, it is noted students of Social Work, English Language and Literature, Civil and Machinery Engineering departments are happy with job opportunities after graduation; students of Statistics, Biyology, Chemistry, Art History, Sociology departments are not happy with job opportunities. Also, students of Social Work, English Language and Literature, Civil and Machinery Engineering departments think that they would find job easily after graduation; students of Statistics, Biyology, Chemistry, Art History, Sociology departments do not think that they can find job easily. It is a reality that the departments with appreciated job opportunities and enabling their graduates to find job easily are the ones that are employed in public sector quickly and numerously. It is seen that in certain periods, certain vocations are employed in public sector. English Language and Literature, Civil and Machinery Engineering are the ones that have been employed easily from past to present. Social Work vocation has just joined to this group. Certain social conditions of the today's world have started to prioritize this vocation.

Most of the students who continue higher education in Turkey prefer the departments with high employment rates or make their choices in accordance with their scores rather than their own desires. When they graduate, they want to find job in public sector and indicate their need for state protection from unemployment risk (Mütevellioğlu et al., 2010) and they prefer the departments that provide these facilities. It is because unemployment anxiety is one of the the most common anxieties among university young (Dökmen, 1989, Akt Akaran Koç and Polat, 2006; Kıran and Taşkiran, 2015: Gizir, 2005). Although in this research most of the students are happy with job opportunities of their departments and think that they would find job easily after graduation, based on some studies, they state that despite their willingness to find job that is suitable to their department, they don't believe that they would find job in accordance with their expectations without any difficulties so because of this situation they experience high level of anxiety (Mütevellioğlu et al., 2010). 
Karakuş, Ö. (2017). Evaluating the vocational thoughts of university students about the departments they are studying. Journal of Human Sciences, 14(3), 2643-2652. doi:10.14687/ihs.v14i3.4696

Students of Midwifery, Veterinary, English Language and Literature, Social Work, Civil and Machinery Engineering departments are happy with their job opportunities after graduation; but students of Statistics, Biology, Chemistry, Art History, Sociology departments are not happy with their job opportunities after graduation. Based on a study focusing on department of Sociology students, students state that they like the learning environment but they think they cannot find job when they graduate (Yllmaz, 2014). Again Students of Midwifery, Veterinary, Social Work, English Language and Literature, Civil and Machinery Engineering departments state that they would not be unemployed; students of Statistics, Biology, Chemistry, Art History, and Sociology departments state that they will be unemployed. The similarity between these two conclusions makes us think about the fact that Social Work, English Language and Literature, Civil and Machinery Engineering departments' ability to find job in public and private sectors.

According to Çaylar's study (2010), despite the differences in terms of the ratios, students of the three faculties (Faculty of Science and Letters, Education and Economic and Administrative Sciences) make some plans regarding their life and career after graduation. When the expectations in terms of finding job and working conditions, difference between Faculty of Science and Letter and Faculty of Economics and Administrative Sciences draws attention. Level of expectations of Faculty of Education students in term of finding a job and working conditions is good; whereas level of expectation of Faculty of Economics and Administrative Sciences students' is medium level and it is founded that level of expectations of Faculty of Science and Letters students' concentrate on good and medium level. There are some differences discovered in terms of the level of expectation from finding job after graduation. While the ratio of the idea that they can find job in line with their level of education is high for Faculty of Education; the ratio is getting lower for Faculty of Science and Letters; and the ratio is even lower in Faculty of Economics and Administrative Sciences. Üstün et al. (2014) finds out that hopelessness scores of students enrolled in Faculty of Education are significantly higher than students enrolled in Health College. Şanll-Kula \& Saraç (2016) in their study figure out that while Faculty of Science and Letters has the highest continual anxiety averages; Physical Medicine and Rehabilitation College has the lowest average. These studies make us think that departments with better job opportunities experience less anxiety and hopelessness compared to the departments with fewer opportunities. In Özpancar et al. (2008) study with nursing students, the first reason of why students prefer this department is finding job easily. According to Alper \& Özdemir (2004) study, the reason of Medicine students to prefer that department is again finding job easily. Again according to a foreign study, the reason for choosing pharmacy is indicated as finding job easily (Wilson et al. 2006).

\section{Conclusion and Suggestions}

Most of the university students choose their departments willingly. What makes university students anxious most is being unemployed. Students want to work in public sector when they graduate. Students see unemployment as not earning income. Most of the students are not happy with the job opportunities of departments they enroll in. Departments that indicate their unhappiness with the job opportunities after graduation are Statistics, Biology, Chemistry, Art History and Sociology. Again the ones who indicate that they will be unemployed are the same departments. By taking into account that those departments are under the Faculty of Science and letters, policies have to be developed. For the unemployment anxiety that students are experiencing, state has to develop new policies related with employment. In order to make students believe that they would find job easily, apart from the departments they enroll in, alternative ways for career development can be provided. 
Karakuş, Ö. (2017). Evaluating the vocational thoughts of university students about the departments they are studying. Journal of Human Sciences, 14(3), 2643-2652. doi:10.14687/ihs.v14i3.4696

\section{Kaynaklar}

Aytaç, S. \& Bayram, N. (2001). Üniversite gençliğinin iş ve eş seçimindeki etkin kriterlerinin Analitik Hiyerarşi Süreci (AHP) ile analizi. Marmara Üniversitesi Sosyal Bilimler Enstitüsü Dergisi, 3 (1), $89-100$.

Alper, Z. \& Özdemir, H. (2004). Uludağ üniversitesi tıp fakültesini tercih eden öğrencilerin kimi sosyo-demografik özellikleri ve mesleğe bakış açları [Some Socio-Demografic Properties and Profession Perspectives of Students who Preferred Uludag University Faculty of Medicine]. Uludağ Üniversitesi Tip Fakültesi Dergisi, 30, 93-6.

Anılan, H., Çemrek, F. \& Anagün, Ş. S. (2008). Ortaöğretim öğrencilerinin meslek seçimi ve üniversite tercihlerine ilişkin görüşleri (Eskişehir örneği) [Career choice and university preference of secondary school students (Eskisehir case)]. e-Journal of New World Sciences Academy Social Sciences, 3(2), 238-249.

Aytaç, S. \& Aşkın, K., (2002). İşsizliğin çalışan birey üzerindeki etkisi: İşsizlik kaygısı, İnsan Kaynaklar, 4(2), 10-20.

Aytaç, S. ve Dursun, S. (2009). Üniversite öğrencileri arasında işsizlik kayg1sı. Uludă̆ Üniversitesi İktisadi ve İdari Bilimler Fakültesi Dergisi, 1, 71-84.

Kars, V., Arslan, N., Erik, L. Avc1, N., Bucaktepe, P.G., Celepkolu, T. \& Şahin,H.A. (2014). Lise son sınıf öğrencilerinin meslek seçiminde karşılaştığı sorunlar ve bu sorunların anksiyete ve depresyonla ilisskisi [The problems during choice of profession and comparison of these problems with anxiety and depression in final year of high school students]. Dicle Trp Dergisi, 41 (1): 187-190.

Çaylar, G. (2010) Üniversite ögrencilerinin gelecek beklentilerine etki eden faktörler, bu faktörlerin birbirleriyle iliskileri ve bireylerin depresyon, anksiyete hislerine olan etkisi. Yüksek Lisans Tezi, Bursa: Uludağ Üniversitesi Sağllk Bilimleri Enstitüsü.

Doğan, A. A. \& Baş, M. (2003). Beden eğitimi ve spor bölümü öğrencilerinin durumluk kayg1 düzeyleri ile başarıları arasındaki ilişkileri [The relations between achievements and level of anxiety of physical education and sports departments students]. Beden Eg̈itimi ve Spor Bilimleri Dergisi, 5 (3), 1-5.

Doğramacı, M. (2008). Meslek seçimi. http://www.geocities.com/egitimcilersitesi_rehberlik/, (01.02.2008'de indirildi)

Gizir, C. A.(2005). Orta Doğu Teknik Üniversitesi Son Sınıf Öğrencilerinin Problemleri Üzerine Bir Çalışma [A Study on the Problems of the Middle East Technical University Senior Students], Mersin Üniversitesi Ë̈itim Fakültesi Dergisi,1(2), 196-213.

Harmancı, S. (2014). Türkiye' de Istihdam ve Isssizllik. Sosyal Bilimler Entitüsü, Yayınlanmamış Yüksek Lisans Tezi, Trabzon: Karadeniz Teknik Üniversitesi Sosyal Bilimler Enstitüsü.

TBMM. (2015). Türkiye'de üniversite mezunu nüfusun işgücü durumu. Ankara: TBMM Araştırma Hizmetleri Başkanlığ Sosyal Politika Bölümü

Kıcır, B. (2010). Üniversite son sınıf öğrencilerinde işsizlik kaygısı: psikolojik etmenler açısından bir inceleme. Ankara: Ankara Üniversitesi, Sosyal Bilimler Enstitüsü, Çalısma Ekonomisi ve Endüstri İlişkileri Anabilim Dalı, Yüksek Lisans Tezi.

Kıran, B. \& Taşkıran, E. G. (2015). Ege Üniversitesi eczacılık fakültesi 1.sınıf öğrencilerinin meslek tercihine etki eden faktörler. Marmara Pharmacentical Journal, 19, 159-167

Kıyak, S. (2006). Genel lise ögrencilerinin meslek seçimi yaparken temel aldĭgr kriterler. İstanbul: Yeditepe Üniversitesi Sosyal Bilimler Enstitüsü Yayınlanmamış Yüksek Lisans Tezi.

Koç, M. \& Polat, Ü. (2006). Üniversite öğrencilerinin ruh sağllğ1 The mental health of university students], Uluslar arasi Insan Bilimleri Dergisi, 3(2). 1-22.

Korkmaz, A. \& Mahiroğulları, A. (2007). Issizlikele mücadelede emek piyasası politikalar, Türkiye ve AB Ülkeleri. Bursa: Ekin Basın Yayın Dağıtım.

Korkut Owen, F. (2008). Mesleki seçimleri etkileyen ana etmenler. (Ed. R. Özyürek). Kariyer Yolculuğu, (ss.1-23). Ankara: Ulusal Ajans 
Karakuş, Ö. (2017). Evaluating the vocational thoughts of university students about the departments they are studying. Journal of Human Sciences, 14(3), 2643-2652. doi:10.14687/ihs.v14i3.4696

Korkut-Owen, F. Kepir, D.D., Özdemir, S., Ulaş, Ö. \& Yilmaz, O. (2012). Üniversite öğrencilerinin bölüm seçme nedenleri [Reasons for university student's program choice]. Mersin Üniversitesi Eğitim Fakültesi Dergisi, 8(3), 135-151.

Kuzgun, Y. (1982). Mesleki rebberlig̈in bireyin yetenek ve ilgilerine uygun meslekleri tanmalarna etkisi. Ankara: Ankara Üniversitesi Yayınları.

Kuzgun, Y. (2004). Meslek rehberliği ve danısmanlğgna giriş. Ankara: Nobel Yayın Dağıtım.

Kuzgun, Y. (2008). Meslek seçiminde bilinmesi gerekenler. Access date: 29.02.2017, Access adres: http://www.gopaml.k12.tr/

Kuzgun, Y. (2003). İlkë̈gretimde rehberlik. Ankara: Nobel Yayın Dağıtım.

Meslek Rehberi. (2008). En saygin meslekler. Access date: 15.10.2016, Access adres: http://www.gopaml.k12.tr/http://www.meslekrehberi.org/meslek tanitimlari/en-sayginmeslekler.html

Meslek Rehberi. (2008). Meslek. Access date: 01.02.2017, Access adres: http://www.meslekrehberi.org/meslek/

Mütevellioğlu, N., Zanbak, M. \& Mert, M. (2010). İşsizlik, üniversiteli gençlik ve gelecek: bir alan araştırmasinın bulguları [Unemployment, college youth, and future: Inspirations from a field study]. C..Ü. İktisadi ve İdari Bilimler Dergisi, 11(1), 207-229.

Özpancar, N., Aydın, N. \& Akansel, N. (2008). Hemşirelik 1. sınıf öğrencilerinin mesleği ile ilgili görüşlerinin belirlenmesi [Determination Of Begining Nursing Students' Perceptions About Nursing Profession]. Cumburiyet Üniversitesi Hemsirelik Yüksekokulu Dergisi, 12, 10-17.

San, A. (1988). Profesyonellik açısndan İstanbul kütü̈paneleri. Türkiye'de Kütüphane Alanında Teori ile Uygulama İlişkisi Sempozyumu (7-8 Mayıs 1987, İstanbul), haz. Meral ALPAY, İstanbul: İ.Ü. Edebiyat Fakültesi, 192-207.

Soyer, S. (1996). Endüstri sosyolojisi. İzmir: Saray Yay.

Şanl1-Kula, K. \& Saraç, T. (2016). Üniversite Öğrencilerinin Gelecek Kayg1sı [The future anxiety of the university students]. Mustafa Kemal Üniversitesi Sosyal Bilimler Enstitüsü Dergisi, 13 (33), 227242

Üstün, G., Şule, D., Kavalalı, T., Öztürk, F., Sapc1 Y. \& Can, S. (2014). Üniversite son sınıf öğrencilerinin iş bulmaya ilişkin umutsuzluk düzeylerinin incelenmesi, Amasya Üniversitesi Eğitim Fakülttesi Dergisi, 3(2), 200-221.

Wilson, K., Jesson, J., Langley, C., Hatfield, K., \& Clarke, L. (2006). Pharmacy undergraduate students: Career choices and expectations ecross a four-year degree programme. Aston University.

Yılmaz, H., Ö., Üre \& Sürücü, A. (1996). Rebberlik ders notlar. Konya.

Yılmaz, S. (2014). Sosyoloji öğretiminde karşlaşılan güçlükler üzerine bir araştırma: Karabük Üniversitesi sosyoloji bölümü örneği [A Research on Challenges in Teaching Sociology: Karabuk University Case Study]. Tarih Kültür ve Sanat Arastırmalar Dergisi, 3(1). 121-150.

Yüksel, İ. (2003). İşsizliğin psiko-sosyal sonuçlarının incelenmesi (Ankara Örneği) [Study of the psycho-social results of unemployment]. Cumburiyet Üniversitesi İktisadi ve İdari Bilimler Dergisi, 4 (2), 21-38. 